\title{
Biophysical, bioinformatical, cellular, and molecular investigations on the effects of graphene oxide nanosheets on the hemoglobin structure and lymphocyte cell cytotoxicity
}

This article was published in the following Dove Press journal:

International Journal of Nanomedicine

Mohammad Mahdi Nejadi

Babadaei, ${ }^{1}, *$ Mina Feli

Moghaddam, ',* Sara Solhvand,'

Ehsan Alizadehmollayaghoob,'

Farnoosh Attar, ${ }^{2}$ Elham

Rajabbeigi, ${ }^{3}$ Keivan Akhtari, ${ }^{4}$

Soyar Sari,' Mojtaba Falahati ${ }^{5}$

'Department of Cellular and Molecular Biology, Faculty of Advance Science and Technology, Pharmaceutical Sciences Branch, Islamic Azad University (IAUPS), Tehran, Iran; 'Department of Biology, Faculty of Food Industry and Agriculture, Standard Research Institute (SRI), Karaj, Iran; ${ }^{3}$ Department of Biochemistry, Faculty of Advance Science and Technology, Medical Sciences Branch, Islamic Azad University, Tehran, Iran; ${ }^{4}$ Department of Physics, University of Kurdistan, Sanandaj, Iran; ${ }^{5}$ Department of Nanotechnology, Faculty of Advance Science and Technology, Pharmaceutical Sciences Branch, Islamic Azad University (IAUPS), Tehran, Iran

*These authors contributed equally to this work
Correspondence: Mojtaba Falahati Department of Nanotechnology, Faculty of Advance Science and Technology, Pharmaceutical Sciences Branch, Islamic Azad University (IAUPS), Tehran, Iran Email falahati@ibb.ut.ac.ir

Soyar Sari

Department of Cellular and Molecular Biology, Faculty of Advance Science and Technology, Pharmaceutical Sciences Branch, Islamic Azad University (IAUPS), Tehran, Iran Email soyarsari@yahoo.com
Background: Implementations of nanoparticles have been receiving great interest in medicine and technology due to their unique characteristics. However, their toxic impacts on the biological system are not well explored.

Aim: This study aims to investigate the influence of fabricated nano graphene oxide (NGO) sheets on the secondary and quaternary structural alterations of human hemoglobin $(\mathrm{Hb})$ and cytotoxicity against lymphocyte cells.

Materials and methods: Different spectroscopic methods, such as extrinsic and synchronous fluorescence spectroscopy and far circular dichroism (CD) spectroscopy, molecular docking investigation, cellular assays (trypan blue exclusion, cellular uptake, ROS, cell cycle, and apoptosis), and molecular assay (fold changes in anti/proapoptotic genes [B-cell lymphoma-2 $\{B C L 2\} / B A X]$ expression levels) were used in this study.

Results: Transmission electron microscopy, X-ray diffraction, Fourier transform infrared spectroscopy, and zeta potential investigations revealed the nano-sized nature of NGOs with good colloidal stability. Extrinsic fluorescence spectroscopy by using 8-anilinonaphthalene-1 -sulfonic acid and synchronous fluorescence spectroscopy showed that NGOs can unfold the quaternary structure of $\mathrm{Hb}$ in the vicinity of Tyr residues. The $\mathrm{CD}$ investigation demonstrated that the $\alpha$-helicity of $\mathrm{Hb}$ experienced substantial alteration upon interaction with increasing concentrations of NGOs. The molecular docking study showed that NGOs interacted with polar residues of $\mathrm{Hb}$. Cellular and molecular assays revealed that NGOs lead to ROS formation, cell cycle arrest, and apoptosis through the $B A X$ and $B C L 2$ pathway.

Conclusion: These data reveal that NGOs can induce some protein structural changes and stimulate cytotoxicity against normal cell targets. Therefore, their applications in healthy systems should be limited.

Keywords: nano graphene oxide, human hemoglobin, lymphocyte cell, fluorescence spectroscopy, circular dichroism spectroscopy, docking, cytotoxicity, ROS, cell cycle, flow cytometry

\section{Introduction}

Graphene is composed of a monoatomic sheet of carbon atoms in a honeycomb matrix and is known as one of the firmest materials ever studied with high tensile strength. ${ }^{1}$ Scientists have demonstrated a potential conflict of interest in this newly designed material due to its distinctive chemical characteristics, and medicinal features. ${ }^{1,2}$ Nano graphene oxide (NGO) is commonly fabricated through Hummers' method. ${ }^{3}$ NGOs provide a hydrophilic structure and their surface is simply functionalized with several functional groups. ${ }^{4,5}$ The unique characteristics of NGOs make them tremendously 
interesting candidates in several biomedical applications. For example, Gupta et $\mathrm{al}^{6}$ demonstrated that iron oxide-reduced graphene oxide (GO) nanohybrid can be used as a carrier for targeted drug delivery and induction of apoptosis in cancer cells. Dowaidar et $\mathrm{al}^{7}$ exhibited that GO in a complex with some peptides can be employed for oligonucleotides transportation. Grande et $\mathrm{al}^{8}$ showed that chitosan-GO nanocomposite provides excellent antimicrobial activity for implementation in food packaging. Yu et $\mathrm{al}^{9}$ demonstrated that self-fabricated hydroxyapatite/GO/chitosan nanocomposite can be applied for bone tissue regeneration. De et $\mathrm{al}^{10}$ exhibited the potential of multifunctional biopolymeric-GO-quantum dot nanoconjugate as nanovehicle in cancer therapy. Zhang et $\mathrm{al}^{11}$ reported a facile GO-mediated fluorescent nanobiosensor for the detection of telomerase assay. Sun et $\mathrm{al}^{12}$ reported in situ fabrication of $\mathrm{GO} /$ gold nanorods (nanohybrids) for potential cancerous cell computed tomography imaging, photothermal ablation, and diagnostics.

However, to utilize NGOs in medical practice, it is crucial to determine their toxicity through in vitro and in vivo investigations employing specific cell lines, proteins, theoretical, and animal models.

Indeed, the safety and adverse effects concerns about NGO and its distinctive health advantage to society are far from solved. Several previous studies have demonstrated that NGO and its nanocomposites stimulate low cell toxicity; ${ }^{13,14}$ however, investigations show conflicting outcomes.

For example, Goreham et $\mathrm{al}^{13}$ showed the low cytotoxicity of unmodified and folic acid-functionalized GO-quantum dots against macrophage and their implementations to fluorescence imaging of immortalized nontumorigenic human epidermal (HaCaT) cells. Peña-Bahamonde et al ${ }^{14}$ also revealed that modification of reduced $\mathrm{GO}$ with polysulfone brushes increases its antibacterial activities and decreases human toxic effects. However, Liao et $\mathrm{al}^{15}$ displayed the cytotoxicity of GO and graphene against erythrocytes and fibroblasts cells in a dose-dependent manner. Moreover, Li et al ${ }^{16}$ depicted that pristine graphene can stimulate cytotoxicity through the reduction of the mitochondrial membrane potential and the formation of intracellular ROS, and then induce apoptosis by switching on the mitochondrial pathways.

Moreover, graphene and NGOs interact strongly with biomacromolecules like proteins through different hydrophobic and hydrophilic interactions, potentially changing their structure and disrupting their function. ${ }^{17}$ However, De et al ${ }^{18}$ demonstrated by fluorescence spectroscopy and circular dichroism (CD) investigation that $\alpha$-chymotrypsin-GO interaction is potentially biocompatible and GO induces no changes on the $\alpha$-chymotrypsin's secondary structure over time.
Therefore, conflicting results have been reported regarding the interaction of NGOs with the protein structure and induced cytotoxicity. The aim of this study was to investigate the interaction of NGOs with human hemoglobin $\mathrm{Hb}$ ) and lymphocyte cell as an in vitro blood system model. Different spectroscopic methods (CD and fluorescence), molecular docking, cellular assays, and molecular assay were performed to address the toxic effects of NGOs on biological systems such as $\mathrm{Hb}$ and lymphocyte cells.

\section{Materials and methods Chemicals and reagents}

$\mathrm{Hb}$, fetal bovine serum, and dimethyl sulfoxide were purchased from Sigma-Aldrich Co (St Louis, MO, USA). All other materials were of analytical grade.

\section{Synthesis of NGOs}

A modified Hummer method was used for the fabrication of NGOs. Graphite powder and $50 \mathrm{~mL}$ sulfuric acid were mixed, 2 g sodium nitrate was added, stirred, $3.7 \mathrm{~g}$ potassium permanganate was added, and the mixture was kept for 2 hours on an ice bath. Then, the temperature was raised to $37^{\circ} \mathrm{C}$ for 2 hours, $46 \mathrm{~mL}$ deionized water was added, stirred for 30 minutes at $90^{\circ} \mathrm{C}$, followed by the addition of $140 \mathrm{~mL}$ deionized water and $16 \mathrm{~mL} \mathrm{H}_{2} \mathrm{O}_{2}(30 \%)$. Samples were then stirred at $30 \mathrm{kHz}$ for 30 minutes, centrifuged $(5,000 \mathrm{rpm}$ for 5 minutes), washed with hydrochloric acid 3\% three times, filtered, and vacuum dried at $90^{\circ} \mathrm{C}$ for 24 hours. Finally, $1 \mathrm{mg}$ of the fabricated NGO was dissolved in $1 \mathrm{~mL}$ of deionized water solution under ultrasonic conditions for 30 minutes.

\section{Characterization of NGOs}

Transmission electron microscopy (TEM) image was captured by Zeiss-EM10C-100 KV microscopes (Carl Zeiss Meditec AG, Jena, Germany) to depict the morphology and size of NGOs. The crystalline structure of NGOs was observed by an X-ray diffractometer (PW1730, voltage: $40 \mathrm{kV}$, current: $30 \mathrm{~mA}$; Philips, Amsterdam, the Netherlands). The Fourier transform infrared spectroscopy (FTIR) spectrum of the NGOs was collected by a VERTEX 70-Bruker IR spectrophotometer (Billerica, MA, USA), resolution $4 \mathrm{~cm}^{-1}$, in the wavelength range of 400-4,000 $\mathrm{cm}^{-1}$. Zeta potential data were determined by a dynamic light scattering instrument (Brookhaven Instruments Corporation, Holtsville, NY, USA).

\section{Extrinsic fluorescence spectroscopy}

The extent of exposure of hydrophobic patches in $\mathrm{Hb}$ $(0.1 \mu \mathrm{g} / \mathrm{mL})$ after incubation with increasing concentrations 
of NGOs $(0.01-10 \mu \mathrm{g} / \mathrm{mL})$ was investigated by their capability to attach with the ANS fluorescent dye. ANS was dissolved in methanol and its concentration was calculated based on the extinction coefficient $(\varepsilon)$ of $5,000 \mathrm{M}^{-1} \mathrm{~cm}^{-1}$ at $350 \mathrm{~nm} .{ }^{19}$ For determination of the hydrophobic surface of $\mathrm{Hb}$ after addition of NGOs, a 50 molar fold excess of ANS was added to the sample and incubated at room temperature in the dark for 5 minutes. The fluorescence intensity was recorded using Cary Eclipse (Agilent Technologies, Santa Clara, CA, USA) fluorescence spectrophotometer with excitation at 380 $\mathrm{nm}$ and emission between 400 and $650 \mathrm{~nm}$.

\section{Synchronous fluorescence spectroscopy}

Fluorescence intensity was read on a Cary Eclipse fluorescence spectrophotometer. Synchronous fluorescence spectroscopy was carried out based on the $\Delta \lambda$ of 20 and $60 \mathrm{~nm}$ to selectively detect microenvironmental changes around tyrosine and tryptophan residues, respectively. Scan rate was fixed at $200 \mathrm{~nm} \mathrm{~min}{ }^{-1}$ and slit widths for emission and excitation were set to 5 and $10 \mathrm{~nm}$, respectively. The protein concentration applied for all fluorescence studies was $0.1 \mu \mathrm{g} / \mathrm{mL}$. Also, the NGOs concentration used for the synchronous fluorescence spectroscopy study was in the range of $0.01-10 \mu \mathrm{g} / \mathrm{mL}$. All fluorescence spectra were corrected against background intensity (pure buffer and NGOs solutions).

\section{CD spectroscopy}

The far CD bands of $\mathrm{Hb}$ at a wavelength range of 190-260 nm in the presence of increasing concentrations of NGOs were explored. The CD experiment was performed with an Aviv model 215 spectropolarimeter (Aviv Biomedical, Inc, Lakewood, NJ, USA) at $25^{\circ} \mathrm{C}$. All runs were carried out in triplicates and data were reported as the average. Also, the $\mathrm{Hb}$ bands were subtracted from those of buffer and NGO intensities. Secondary structural alterations of $\mathrm{Hb}$ with a concentration of $0.2 \mu \mathrm{g} / \mathrm{mL}$ ( $\mathrm{pH} 7.4,10 \mathrm{mM}$ phosphate buffer) were determined after addition of increasing concentrations of NGOs ranging from 0.02 to $20 \mu \mathrm{g} / \mathrm{mL}$. The $\alpha$-helix content of $\mathrm{Hb}$ was then estimated by CDNN software (Lakewood, NJ, USA) from mean residue ellipticity (MRE, Leatherhead, Surrey, UK) values at $208 \mathrm{~nm}$ based on Equation 1:

$$
\alpha \text {-helix }(\%)=\frac{\left(-\mathrm{MRE}_{208}-4,000\right)}{(33,000-4,000)} \times 100
$$

where $\mathrm{MRE}_{208}$ exhibits the measured MRE value at $208 \mathrm{~nm}$, 4,000 is the MRE of the $\beta$-form and random coil conformation at $208 \mathrm{~nm}$, and 33,000 demonstrates the MRE value of the pure $\alpha$-helix at $208 \mathrm{~nm}$.

$\mathrm{MRE}_{208}$ can be calculated from Equation 2:

$$
\mathrm{MRE}_{208}=\frac{\theta(\text { mdeg })}{C_{p} n l 10}
$$

where, $\theta$ is the observed $\mathrm{CD}, C_{p}$ displays the molar concentration of $\mathrm{Hb}, n$ is the number of amino acid residues, and $l$ is the path length of the cuvette.

\section{Molecular docking study}

A $3 \times 3 \mathrm{~nm}$ GO nanosheet with carboxyl terminal groups was optimized using universal force field (UFF) which used the Avogadro software (Libavogadro Library, Pittsburgh, PA, USA). ${ }^{20}$ This cluster was used as the NGO model. Molecular docking was carried out by HEX 6.3 software (Aberdeen, Scotland, UK). ${ }^{21}$

\section{Cell culture}

Human lymphocyte cell was obtained from the National Institute of Genetic Engineering and Biotechnology, Tehran, Iran, under approval from the Ethical Committee of the Pharmaceutical Sciences Branch, Islamic Azad University of Tehran. ${ }^{22}$ The cells were cultured in RPMI-1640 medium containing $12.5 \%$ fetal bovine serum, $100 \mathrm{U} / \mathrm{mL}$ penicillin, and $100 \mu \mathrm{g} / \mathrm{mL}$ streptomycin. The cell culture was incubated at $37^{\circ} \mathrm{C}$ in a humidified incubator containing $5 \% \mathrm{CO}_{2}$. Phytohemagglutinin was also added to stimulate lymphocyte cell proliferation. ${ }^{22}$

\section{Trypan blue exclusion assay}

Cell viability was examined by trypan blue exclusion assay. Lymphocyte cells were cultured at a density of $1 \times 10^{4}$ cells per well. After 24 hours, the cells were treated with varying concentrations of $\operatorname{NGOs}(0,1,10,20,50$, and $100 \mu \mathrm{g} / \mathrm{mL})$ for 24 hours. Afterwards, they were collected and stained with $0.4 \%$ trypan blue. The trypan blue-positive and -negative cells for each dose were determined by a hemocytometer. Three independent experiments were run.

\section{Cellular uptake of NGOs}

The uptake of NGOs was investigated by flow cytometry. ${ }^{22}$ Side-scattered light (SSC) is normally influenced by intracellular compositions whereas forward-scattered light (FSC) is generally affected by cell size; however, both SSC and FSC also alter upon cellular internalization of particles. The lymphocyte cells were incubated with $\mathrm{IC}_{50}$ concentrations of NGOs for 24 hours, and afterwards the cells were 
harvested and analyzed by flow cytometry (FACSCalibur; BD Biosciences, San Jose, CA, USA).

\section{Measurement of intracellular ROS levels by flow cytometry}

The formation of intracellular ROS was assayed by flow cytometry utilizing the fluorescent probe $2^{\prime}, 7^{\prime}$ dichlorofluorescein diacetate (DCFH-DA). Lymphocyte cells were treated with $\mathrm{IC}_{50}$ concentration of NGOs for 24 hours. Afterwards, the cells were incubated with $50 \mu \mathrm{mol} / \mathrm{L}$ of DCFH-DA for 30 minutes in the dark. Then, the cells were washed with PBS, collected, and resuspended in PBS. The fluorescence intensity of $2^{\prime}, 7^{\prime}$-dichlorofluorescein was then read using flow cytometry (FACSCalibur).

\section{Cell cycle analysis by flow cytometry}

Cell cycle assay was investigated to detect the quantitative distribution of cells in G0, G1, S, and G2/M phases. The cells were treated with $\mathrm{IC}_{50}$ concentrations of NGOs for 24 hours, harvested, fixed, washed in PBS, and stained with propidium iodide (PI) and RNaseA in PBS for 30 minutes at room temperature. The samples were assayed by flow cytometry (FACSCalibur).

\section{Apoptosis detection by flow cytometry}

The quantitative analysis of apoptosis after treatment with $\mathrm{IC}_{50}$ concentration of NGOs was done using flow cytometry (FACSCalibur). Lymphocyte cells were treated with $\mathrm{IC}_{50}$ concentration of NGO for 24 hours, harvested, washed in PBS, resuspended in Annexin- $\mathrm{V}$ binding, stained with Annexin V-FITC for 15 minutes, and stained with PI for 15 minutes. The staining data were then explored to quantitatively analyze the apoptosis induction by NGOs.

\section{Real-time PCR analysis}

The expression level of B-cell lymphoma-2 (BCL2) and BAX genes was determined by real-time PCR analysis. TRIzol reagent (Thermo Fisher Scientific, Waltham, MA, USA) was used to extract total RNA according to the manufacturer's instructions. The synthesis of cDNA was then carried out by RevertAid first-strand cDNA synthesis kit (Takara, Japan) according to the manufacturer's instructions. The primer sequences are summarized in Table 1.

Quantitative real time-PCR was performed on an ABI Step One Sequence Detection System (Thermo Fisher Scientific) by SYBR ${ }^{\circledR}$ Premix Taq $^{\mathrm{TM}}$ II (Takara, Japan). The relative expression levels of $B C L 2$ and $B A X$ were determined in comparison with GAPDH as an endogenous control gene.
Table I Primer sequences of GAPDH, BCL2, and BAX genes

\begin{tabular}{l|l|l|l}
\hline Gene & Forward and reverse primers & $\begin{array}{l}\text { PCR } \\
\text { fragment } \\
\text { size (bp) }\end{array}$ & Length \\
\hline GAPDH & ACACCCACTCCTCCACCTTTG & 112 & 21 \\
& TCCACCACCCTGTTGCTGTAG & & 21 \\
BCL2 & AACGTGCCTCATGAAATAAAG & 121 & 21 \\
& TTATTGGATGTGCTTTGCATTC & & 22 \\
BAX & GGGTGGTTGGGTGAGACTC & 199 & 19 \\
& AGACACGTAAGGAAAACGCATTA & & 23 \\
\hline
\end{tabular}

Comparative threshold cycle $\left(2^{-\Delta \Delta C T}\right)$ method was employed to analyze the data.

\section{Statistical analyses}

All data are reported as means \pm SD of three independent experiments. Data from the negative control and treated groups were statistically analyzed using one-way ANOVA. ${ }^{*} P$-value $<0.05$ was considered statically significant.

\section{Results}

Figure 1A shows the TEM visualization of the NGOs. As demonstrated, the NGOs display very thin layers with diameter distribution of $20 \mathrm{~nm}$. Figure 1B depicts the X-ray diffraction (XRD) pattern of NGO which shows a broad diffraction peak that appears around $10^{\circ}$. This XRD pattern is in accordance with already reported XRD data of NGOs. ${ }^{23}$ Figure 1C exhibits the FTIR spectrum of NGOs. In the FTIR band of NGOs, strong and broad $\mathrm{O}-\mathrm{H}$ stretching vibration band at $3,430 \mathrm{~cm}^{-1}, \mathrm{C}=\mathrm{O}$ stretching band at $1,725 \mathrm{~cm}^{-1}, \mathrm{O}-\mathrm{H}$ bending band at $1,410 \mathrm{~cm}^{-1}$, and $\mathrm{C}-\mathrm{O}$ stretching vibration at $1,095 \mathrm{~cm}^{-1}$ were detected. These data are in good agreement with the already published data for NGOs. ${ }^{24}$ Zeta potential data were also collected to determine the charge distribution and colloidal stability of NGOs. It was shown that the zeta potential values of NGOs in deionized water and cell culture medium were around $-49.59 \pm 3.71$ and $-31.14 \mathrm{mV}$, respectively. These data depict a relatively good colloidal dispersion of the NGOs in both deionized water and cell culture medium.

\section{ANS fluorescent experiment}

ANS can bind to the hydrophobic portions of proteins. Indeed, unfolded proteins due to exposed hydrophobic moieties are prone to provide an environment to establish nonpolar-nonpolar interactions with ANS. Figure 2 displays that upon addition of increasing concentrations of NGOs to $\mathrm{Hb}$ solution, the signal intensity of ANS increases, indicating that $\mathrm{Hb}$ has experienced substantial denaturation and subsequent unfolding in the globular 

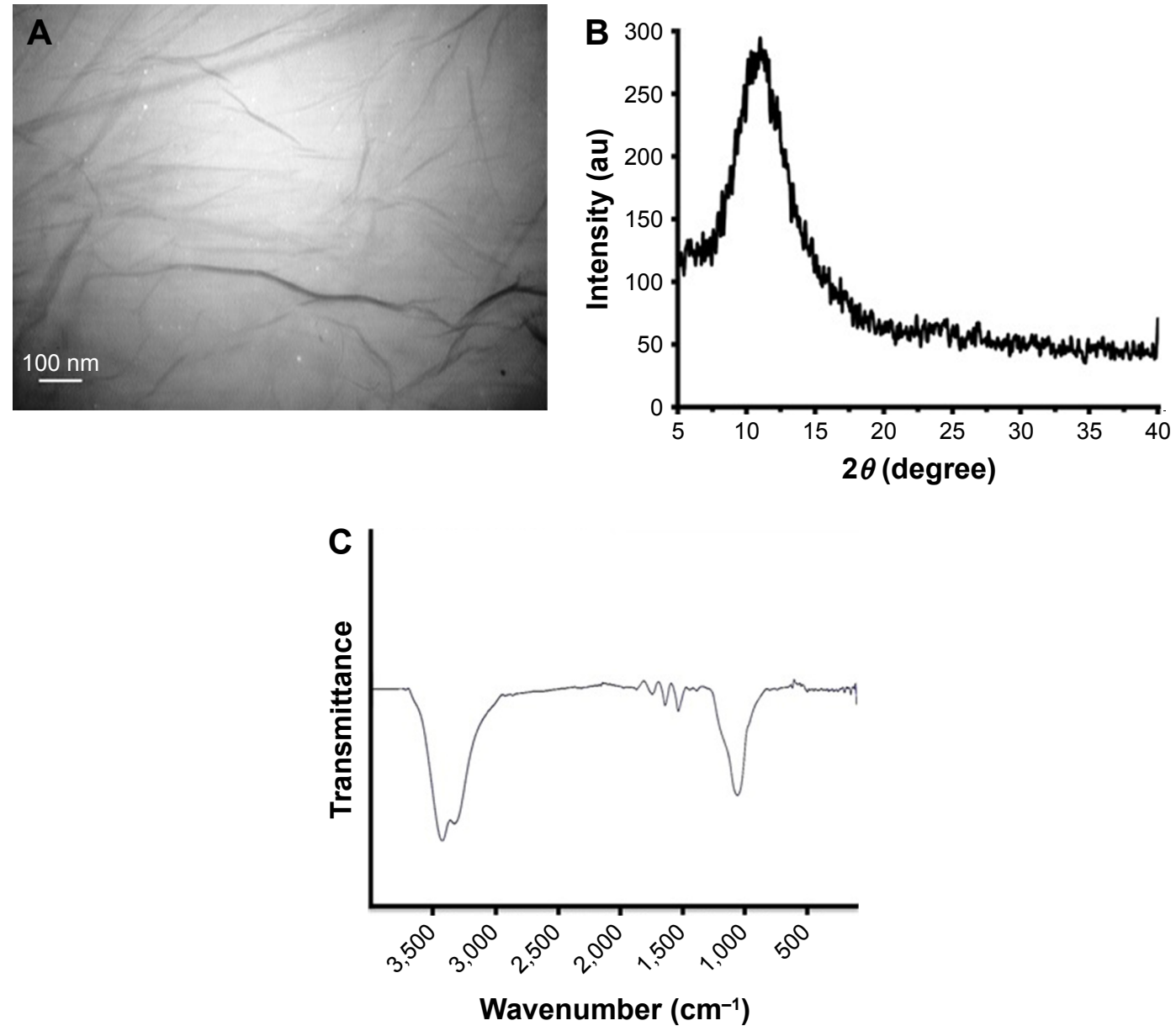

Figure I The TEM image of NGOs (A), the XRD pattern of GO (B), the FTIR spectrum of NGOs (C).

Abbreviations: TEM, transmission electron microscopy; XRD, X-ray diffraction; FTIR, Fourier transform infrared spectroscopy; GO, graphene oxide; NGO, nano graphene oxide.

structure. Also, a marked blue shift from 504 to $492 \mathrm{~nm}$ is detected after addition of NGOs to the Hb solution, determining the exposure of hydrophobic residues on the protein surface.

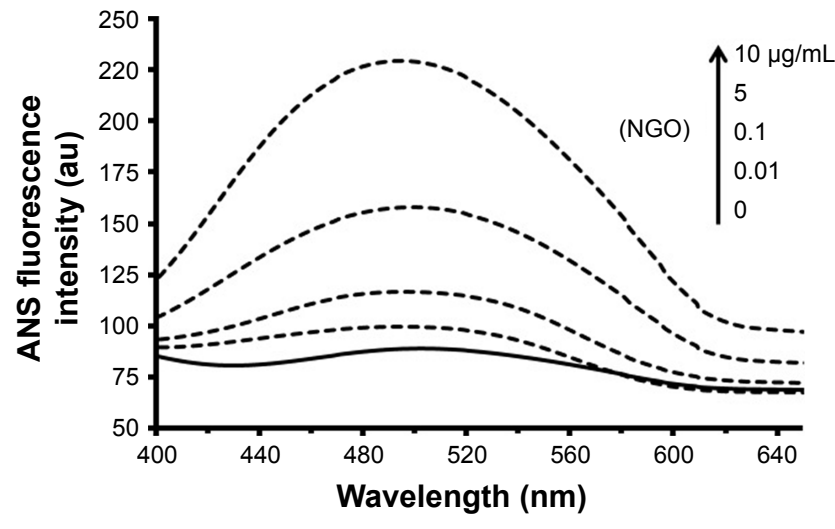

Figure 2 The signal intensity of ANS after addition of increasing concentrations of NGOs $(0,0.01,0.1,5$, and $10 \mu \mathrm{g} / \mathrm{mL})$ to $\mathrm{Hb}$ solution $(0.1 \mu \mathrm{g} / \mathrm{mL})$.

Abbreviations: ANS, 8-anilinonaphthalene-I-sulfonic acid; NGO, nano graphene oxide; $\mathrm{Hb}$, hemoglobin.

\section{Synchronous fluorescence spectroscopy}

Synchronous fluorescence spectroscopy is known as a potential method to investigate the microenvironmental changes around tyrosine and tryptophan residues..$^{25}$ The synchronous fluorescence spectrum shows alteration in the microenvironment of tyrosine amino acids examined with $\Delta \lambda=15 \mathrm{~nm}$, and the same for tryptophan amino acids investigated with $\Delta \lambda=60 \mathrm{~nm} .{ }^{25}$ Herein, the same $\Delta \lambda$ values were fixed to consider microenvironmental changes around tyrosine and tryptophan residues after incubation of $\mathrm{Hb}$ with NGOs. Figure $3 \mathrm{~A}$ shows that, at $\Delta \lambda=15 \mathrm{~nm}$, a considerable red shift is observed from 309 to $314 \mathrm{~nm}$ determining the probability of alteration in the microenvironment of tyrosine residues. However, at $\Delta \lambda=60 \mathrm{~nm}$ (Figure 3B), no marked shift in the maximum wavelength of the $\mathrm{Hb}$ sample was detected after addition of increasing concentrations of NGOs, revealing no substantial structural changes around tryptophan residues. Therefore, it may be indicated that the polarity around 
A

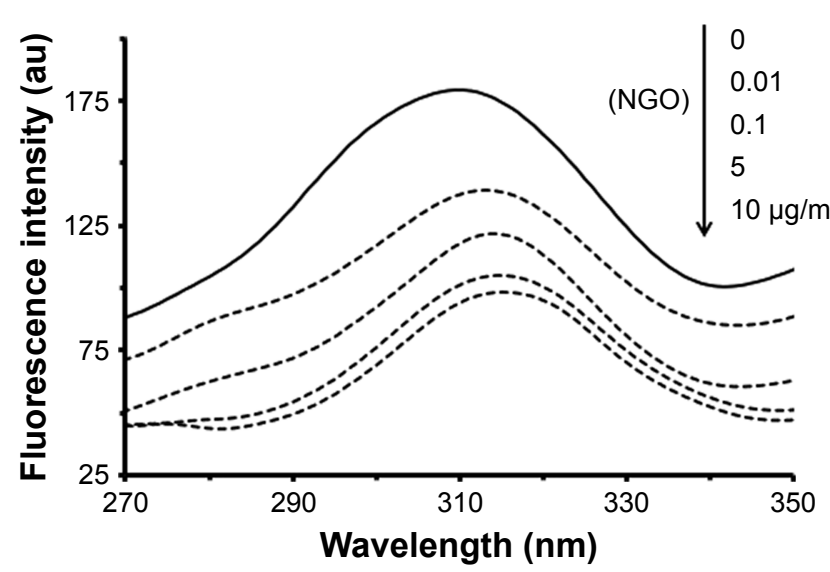

B

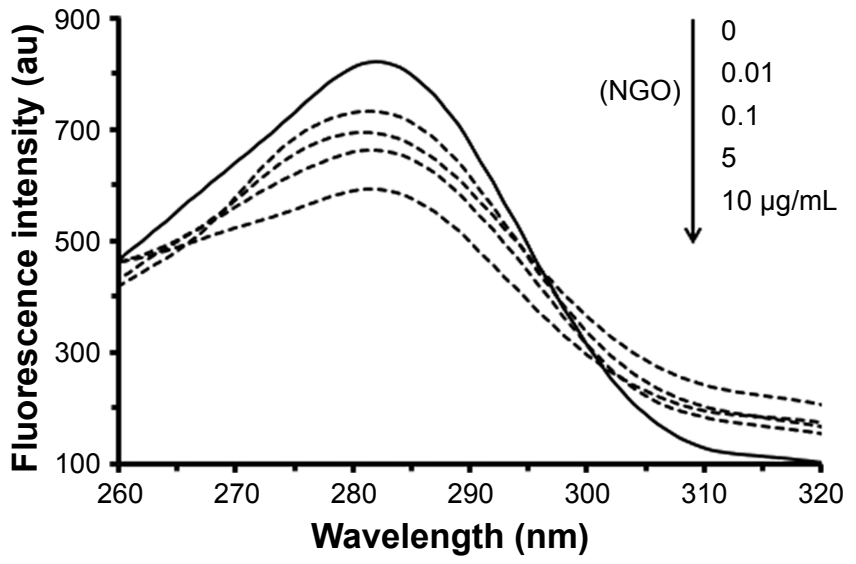

Figure 3 Synchronous fluorescence spectroscopy of $\mathrm{Hb}(0.1 \mu \mathrm{g} / \mathrm{mL})$ after addition of increasing concentrations of $\mathrm{NGOs}$ with $\Delta \lambda=15 \mathrm{~nm}(\mathbf{A})$ and $60 \mathrm{~nm}(\mathbf{B})$. Abbreviations: NGO, nano graphene oxide; Hb, hemoglobin.

tyrosine residues of $\mathrm{Hb}$ enhances and the hydrophobicity reduces in the presence of NGOs.

\section{CD study}

CD spectroscopy has been widely employed as a simple and sensitive method for exploring structural changes of protein after addition of ligands such as nanoparticles (NPs). ${ }^{26}$ The $\mathrm{CD}$ bands of $\mathrm{Hb}$ show two characteristic minima at 222 and $208 \mathrm{~nm}$, featuring the dominant $\alpha$-helix structure of $\mathrm{Hb}^{26}$ Indeed, any changes to the helical structure of $\mathrm{Hb}$ result in protein dysfunction. Therefore, determining the percentage of the secondary structure of $\mathrm{Hb}$ in the presence of varying concentrations of NGOs can provide useful information regarding the adverse effects of NGOs on the native structure of $\mathrm{Hb}$. Figure 4 demonstrates that the minimum ellipticity of $\mathrm{Hb}$ changes in the presence of increasing concentrations of NGOs. The percentage of the secondary structure of $\mathrm{Hb}$ in the

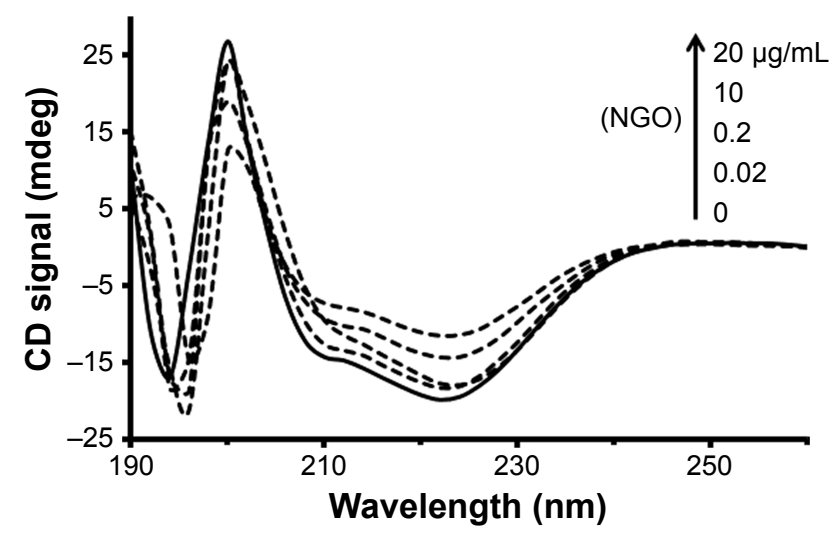

Figure 4 The $C D$ signal after addition of increasing concentrations of NGOs $(0,0.02,0.2,10$, and $20 \mu \mathrm{g} / \mathrm{mL})$ to $\mathrm{Hb}$ solution $(0.2 \mu \mathrm{g} / \mathrm{mL})$.

Abbreviations: $C D$, circular dichroism; $\mathrm{NGO}$, nano graphene oxide; $\mathrm{Hb}$, hemoglobin. presence of varying concentrations of NGOs is summarized in Table 2. It may be indicated that after addition of NGOs the percentage of $\alpha$-helix content reduces as the concentration of NGOs increases. Indeed, the unfolded species of $\mathrm{Hb}$ ( $\% \beta$-sheet, $\%$ turn, and $\%$ random coil) increases after addition of NGOs, revealing the denaturation of $\mathrm{Hb}$ in the presence of NGOs. These data may infer that the adsorption of $\mathrm{Hb}$ onto the NGOs surface results in the alteration of the secondary structure of the protein.

\section{Molecular docking study}

A $3 \times 3 \mathrm{~nm}$ GO nanosheet modified with carboxyl functional moieties was optimized employing UFF which used the Avogadro software (Figure 5). Molecular docking investigation is widely used as a descent approach in the biochemical and biophysical studies to explore in detail the interaction of ligand with proteins. ${ }^{27}$ The crystallographic structure of $\mathrm{Hb}$ (PDB ID 2H35) was obtained from the online Research Collaboratory for Structural Bioinformatics Protein Data Bank (http://www.pdb.org). Molecular docking was performed with a designed $\mathrm{GO}$ nanosheet. The resulting binding energy was calculated to be -892.35 E-value. The docked site was visualized by CHIMERA (www.cgl.ucsf.edu/chimera) and

Table 2 Percentage of secondary structure of $\mathrm{Hb}$ in the presence of varying concentrations of NGOs

\begin{tabular}{l|l|l|l|l}
\hline GO $(\mu \mathrm{g} / \mathrm{mL})$ & $\% \alpha$-helix & $\% \beta$-sheet & $\%$ turn & $\%$ random coil \\
\hline 0 & 61.23 & 14.37 & 12.84 & 11.56 \\
5 & 60.48 & 14.68 & 13.02 & 11.82 \\
10 & 57.71 & 15.38 & 14.31 & 12.60 \\
15 & 54.27 & 16.48 & 16.12 & 13.13 \\
25 & 51.61 & 17.29 & 17.25 & 13.85 \\
\hline
\end{tabular}

Abbreviations: GO, graphene oxide; NGO, nano graphene oxide. 
A

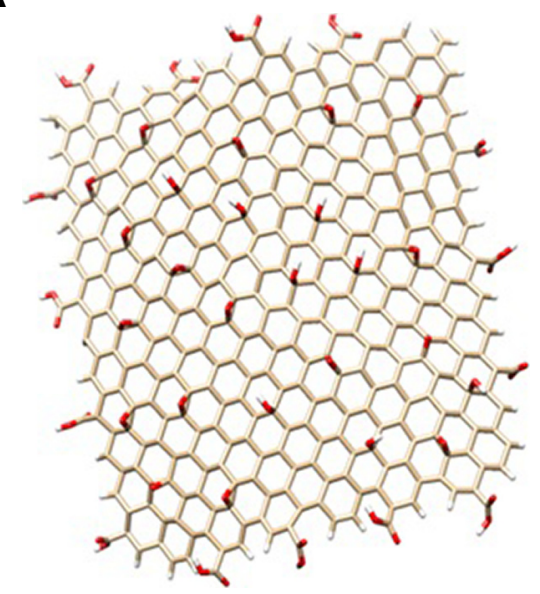

B
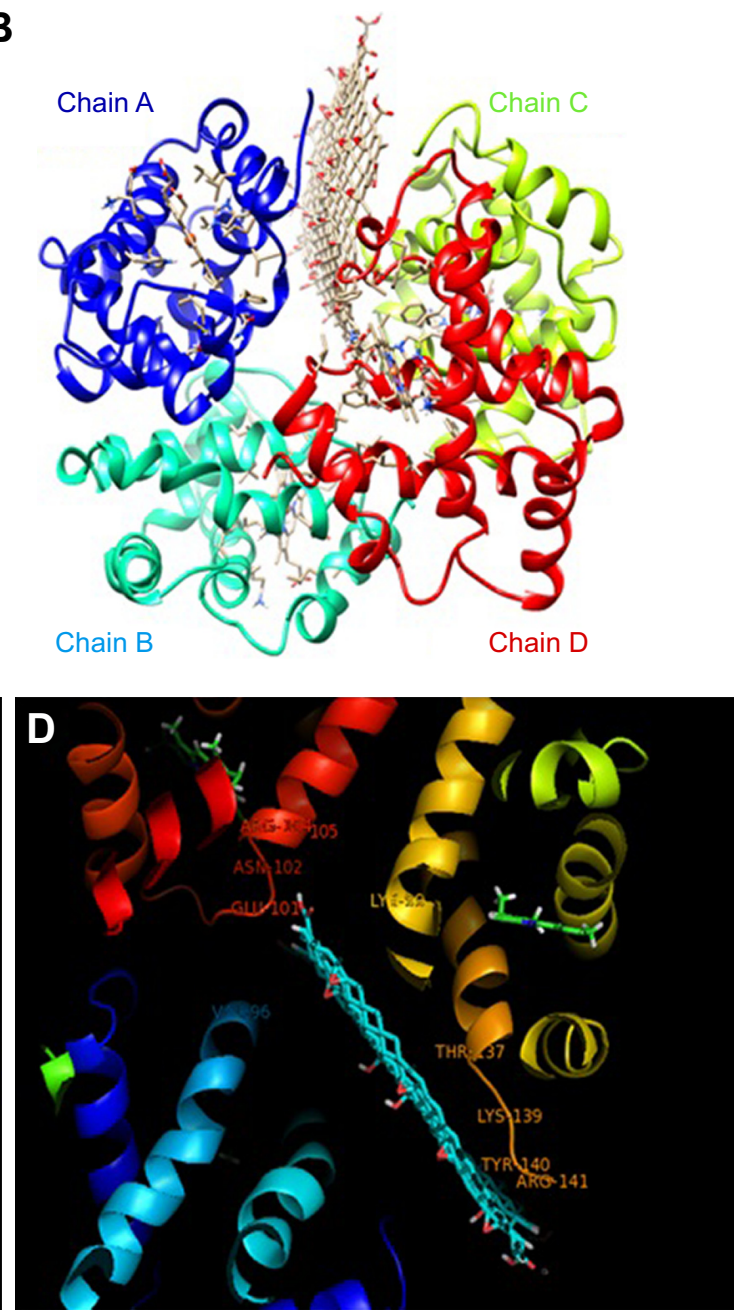

Figure $53 \times 3 \mathrm{~nm}$ GO nanosheet modified with carboxyl functional moieties (A), the docked site (B), two rotational views of docked pose (C, D). Abbreviation: GO, graphene oxide.

PyMOL (http://pymol.sourceforge.net/) graphical tools. The docked site is shown in Figure 5B. The GO nanosheet with interacting residues within $4 \AA$ and the spatial conformation in the binding site are depicted in Figure 5C and D. The nearest interacting residues are Thr-134.A, Thr-137.A, Ser-138.A, Lys-139.A, Thr-140.A, Val-96.A, Pro-100.D, Glu-101.D, Asn-102.D, Arg 141.C, Tyr-140.C, Lys-139.C, Thr-137.C, and Lys-99.C.

Therefore, it was shown that the interaction of NGOs with $\mathrm{Hb}$ could occur by means of polar-polar forces and these interactions are stable when protein is in the globular form with distribution of hydrophilic polar residues on its surface. Also, synchronous fluorescence spectroscopy demonstrated that Tyr residues moved to a more hydrophilic residue after interaction of $\mathrm{Hb}$ with NGOs. The molecular docking study revealed that Tyr-140.C may have experienced a displacement in the structure of the protein.

\section{Trypan blue exclusion assay}

The cytotoxicity of NGOs against human lymphocyte cell line was explored by the well-known Trypan blue exclusion assay. In this regard, increasing doses of NGOs from 1 to $100 \mu \mathrm{g} / \mathrm{mL}$ were incubated with cells for 24 hours to assess the NGOs-stimulated cytotoxicity. Figure 6 shows that the viability of cells decreases to $96.18 \pm 8.75,85.00 \pm 8.30$, $63.19 \pm 10.06,42.94 \pm 4.06$, and $22.29 \% \pm 4.58 \%$ after increasing the concentrations of NGOs to $1,10,20,50$, and $100 \mu \mathrm{g} / \mathrm{mL}$, respectively. It also shows that lymphocyte viability decreases as the concentration of NGOs increases and $\mathrm{IC}_{50}$ concentration was determined to be $50.07+7.2 \mu \mathrm{g} / \mathrm{mL}$. This concentration was used for ROS, cell cycle, and apoptosis assays.

It should be noted that the NGOs induced significant cytotoxicity against lymphocyte cell line at $10 \mu \mathrm{g} / \mathrm{mL}$ and concentrations $<10 \mu \mathrm{g} / \mathrm{mL}$ of NGOs do not show any cytotoxic effects against lymphocyte cell. Therefore, investigations can 


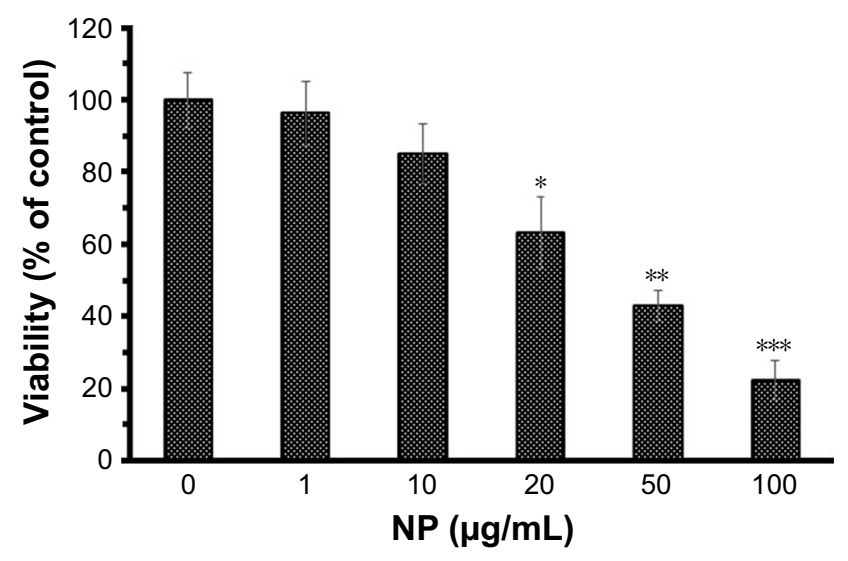

Figure $\mathbf{6}$ The viability of lymphocyte cell against increasing concentrations of NGOs $(\mathrm{I}, 10,20,50$, and $100 \mu \mathrm{g} / \mathrm{mL})$ by Trypan blue exclusion test.

Note: $* P<0.05, * * P<0.01$, and $* * * P<0.001$ compared with the negative control sample.

Abbreviations: NGO, nano graphene oxide; NP, nanoparticle.

be made in the future on the anticancer effect of NGOs with lower doses of $10 \mu \mathrm{g} / \mathrm{mL}$. If NGOs can inhibit the proliferation of cancerous cells in the dose range of $1-10 \mu \mathrm{g} / \mathrm{mL}$, then they can be applied for cancer therapy.

The cell uptake, ROS, cell cycle, and apoptosis assays were performed to detect the mechanism of cytotoxicity of NGOs against human lymphocyte cells.

\section{Cellular uptake}

The cytoplasmic uptake of NGOs by lymphocytes was investigated by flow cytometry. Figure 7A and B shows the histogram of normal cells and NGOs-incubated cells, respectively. A significant enhancement in the fluorescent intensity of SSC and a reduction in FSC (Figure 7B) were observed after lymphocyte cells were exposed to the $\mathrm{IC}_{50}$ concentration of NGOs for 24 hours. This is well documented to be a result of light reflection that derived from cellular NP internalization. ${ }^{22}$

\section{Intracellular ROS generation}

The $\mathrm{IC}_{50}$ dose of NGOs was added to the lymphocyte cell culture for 24 hours and intracellular ROS formation was investigated by flow cytometry. The flow cytometry study showed that the mean fluorescence intensity was 1,088 for the negative control sample (Figure 8A). However, the addition of NGOs to lymphocyte enhanced the mean fluorescence intensity to $2,188(* * P<0.01)$ (Figure $8 \mathrm{~B})$. This outcome indicated that NGOs markedly induced the elevation of intracellular ROS level in the lymphocyte cell (Figure 8C).

\section{Cell cycle assay}

The cell cycle test was carried out to investigate whether NGOs stimulate cell cycle arrest and apoptosis. The apoptotic cells depict an increase in the population of cells in $\mathrm{G}_{0}$ phase. As exhibited in Figure 9A, the population of cells in $\mathrm{G}_{0}$ is $9.52 \%$. However, the addition of $\mathrm{IC}_{50}$ concentration of NGOs leads to an increase of the percentage of cells in the $\mathrm{G}_{0}$ phase to $52.24 \%(* * * P<0.001)$ (Figure 9B). Hence, the number of apoptotic cells significantly increased in the presence of $\mathrm{IC}_{50}$ concentration of NGOs for 24 hours. The data depicted that the $\mathrm{IC}_{50}$ concentration of NGOs reduced the viability of lymphocyte cell through apoptosis induction. It can be also seen that the number of cells in the G2/M phase significantly decreases after addition of NGOs $(* * P<0.01)$ compared to the control group (Figure 9C). However, the population of cells in the S-phase is not markedly changed after addition of NGOs relative to the negative control. These data indicated that NGOs inhibit the proliferation of lymphocyte cell along
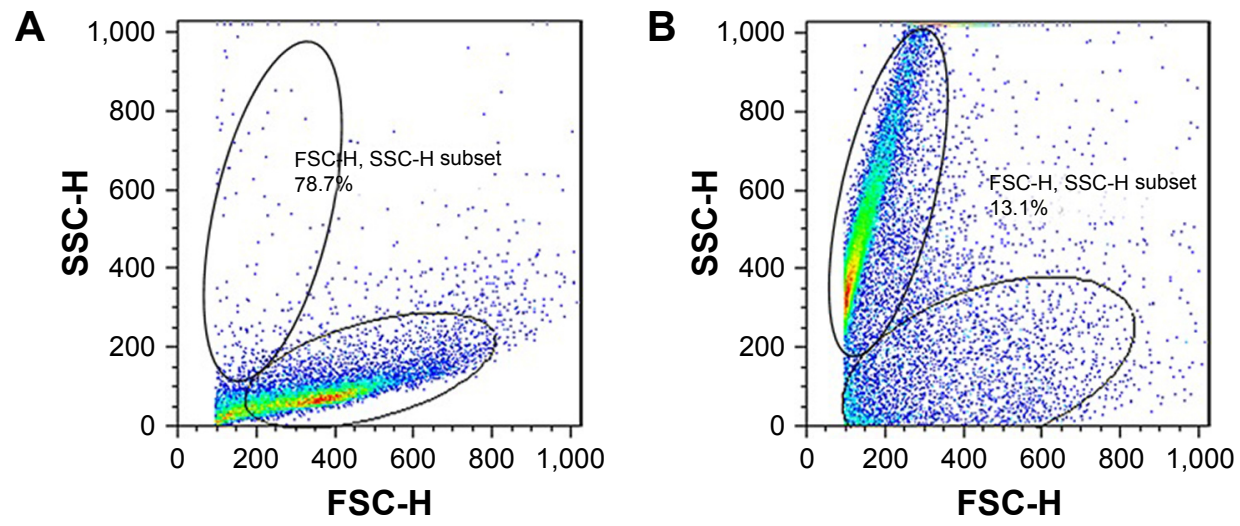

Figure 7 The study of NGOs internalization into the cytoplasm of lymphocyte cells by flow cytometric light scatter.

Notes: Lymphocyte cells with $0 \mu \mathrm{g} / \mathrm{mL}$ of NGOs (A) and with $\mathrm{IC}_{50}$ concentration of NGOs under dark conditions for 24 hours (B). The fluorescent intensity of both SSC and FSC was analyzed by flow cytometry.

Abbreviations: NGO, nano graphene oxide; SSC, side-scattered light; FSC, forward-scattered light. 


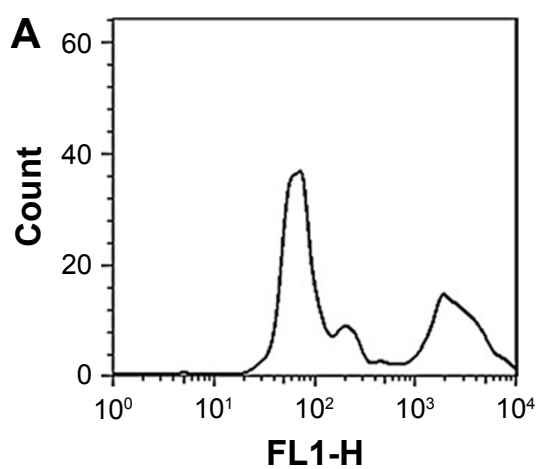

\section{C}
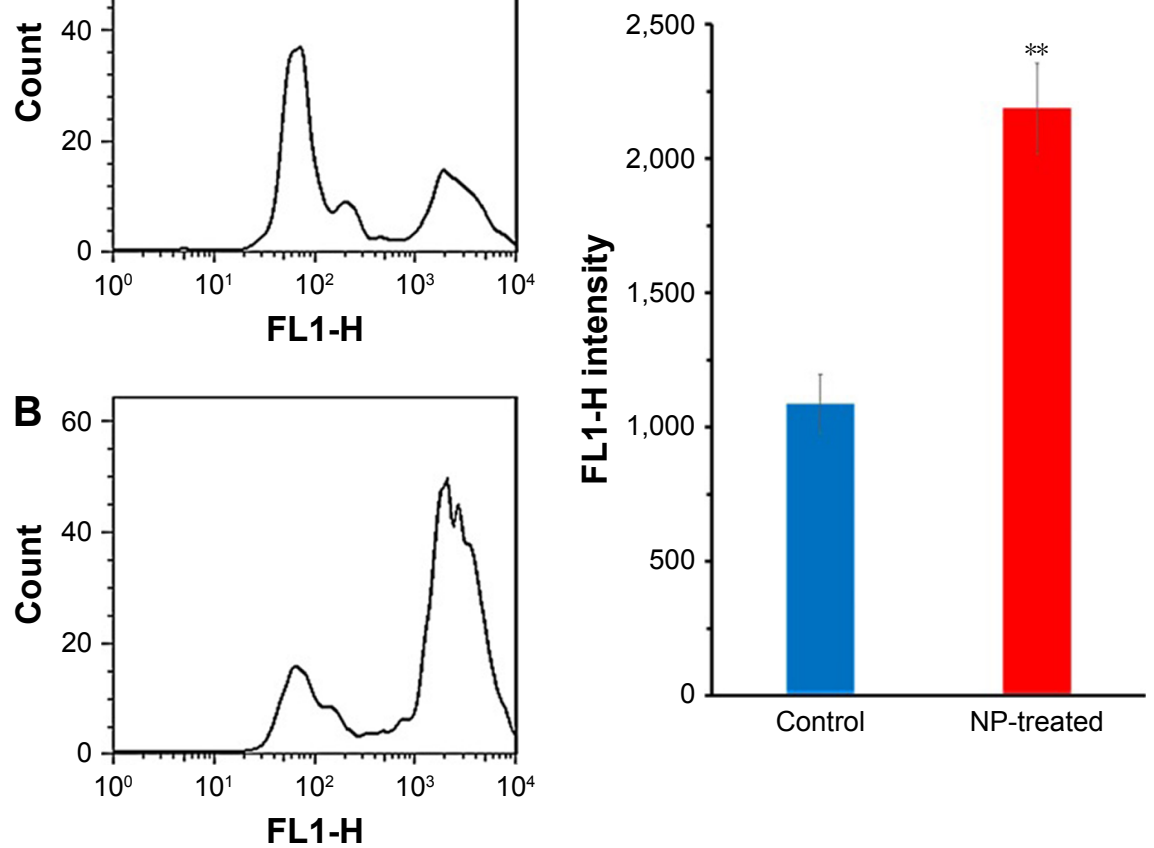

Figure 8 Mean ROS formation in the lymphocyte cell in the absence (A) and presence of $I_{50}$ concentration of NGOs (B). The quantitative analysis was plotted to show the ROS result based on the $\mathrm{FLI}-\mathrm{H}$ intensity $(\mathbf{C})$.

Note: ${ }^{* * P}<0.01$ compared with the negative control sample.

Abbreviations: NGO, nano graphene oxide; NP, nanoparticle.
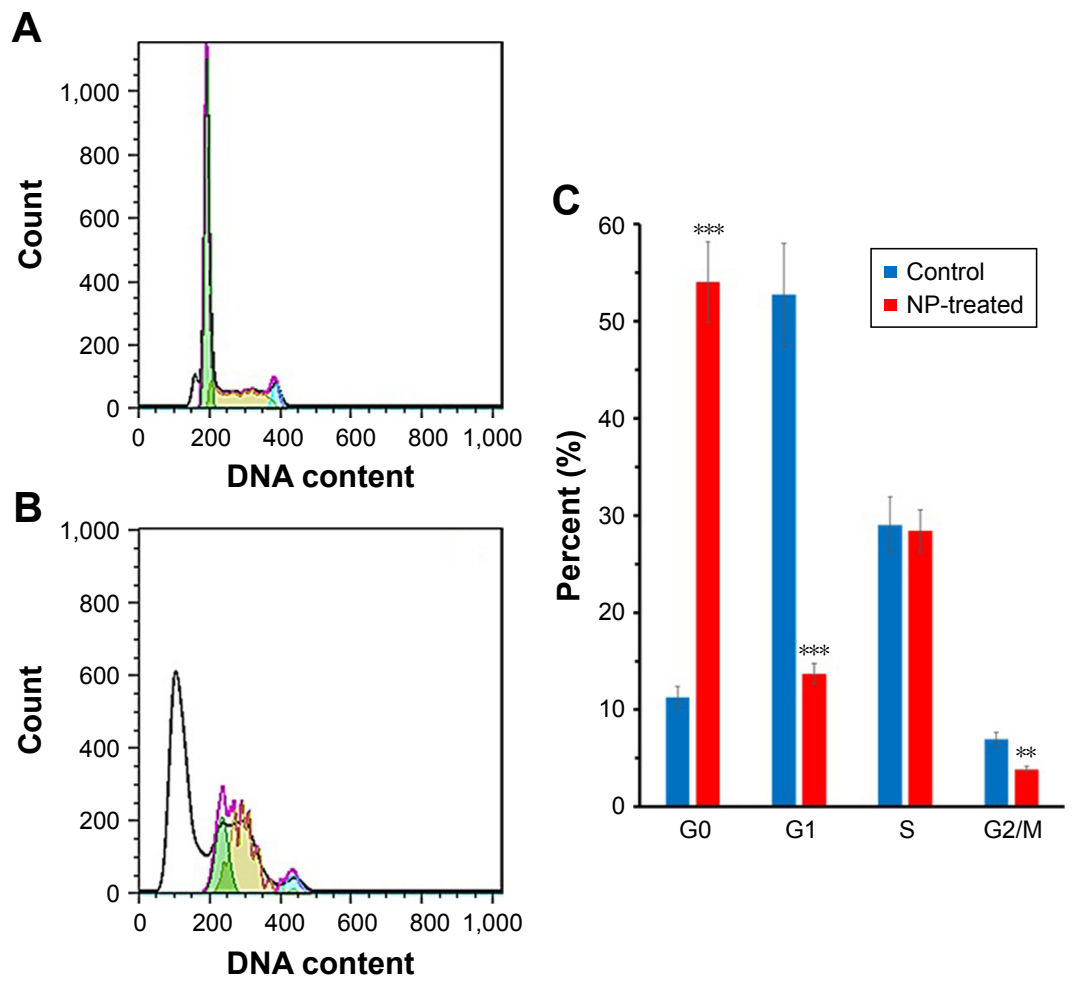

Figure 9 Lymphocyte cells were incubated with $I_{50}$ concentrations of NGOs for 24 hours and the cell cycle phases in the absence (A) and presence of NGOs (B) were determined by flow cytometry. The quantitative analysis was plotted to show the population of cell cycle phases (C).

Note: $* * P<0.01$ and $* * * P<0.001$ compared with the negative control sample.

Abbreviations: NGO, nano graphene oxide; NP, nanoparticle. 
with cytotoxicity through apoptosis induction. However, NGOs do not interfere with the synthesis of DNA and the number of cells in the S-phase.

\section{Flow cytometry assay}

The lymphocyte cells were incubated with an $\mathrm{IC}_{50}$ dose of NGOs for 24 hours, and the quantity of apoptotic cells was calculated by flow cytometry (Figure 10A and B). As shown in Figure 10C, after incubation, the percentage of early apoptotic cells $(\mathrm{Q} 2)$, late apoptotic cells $(\mathrm{Q} 3)$, and necrotic cells (Q4) increased to $23.2 \pm 3.86\left({ }^{*} P<0.05\right), 29.7 \pm 4.95$ (*** $P<0.001)$, and $13.4 \% \pm 2.23 \%(* * * P<0.001)$ over those of the control $16.9 \pm 2.41,1.29 \pm 0.18$, and $1.85 \% \pm 0.26 \%$, respectively. Statistically significant differences were reported between the NGOs-incubated group and the negative control sample in the induction of early apoptosis, late apoptosis, and necrosis.

\section{Genotoxicity assay}

The fold changes in expression of $B C L 2$ and $B A X$ genes in the absence and presence of different concentrations of NGOs $(50,100$, and $200 \mu \mathrm{g} / \mathrm{mL})$ compared to the control group were as follows: the expression of BCL2 in the cells incubated with $100 \mu \mathrm{g} / \mathrm{mL}(* P<0.05)$ and $200 \mu \mathrm{g} / \mathrm{mL}$ $(* * P<0.01)$ of NGOs for 24 hours significantly decreased in comparison with the control sample (Figure 11A). BAX demonstrated a significant increase in the incubated cells with 100 $\mu \mathrm{g} / \mathrm{mL}\left({ }^{*} P<0.05\right)$ and $200 \mu \mathrm{g} / \mathrm{mL}\left({ }^{*} P<0.05\right)$ of NGOs for

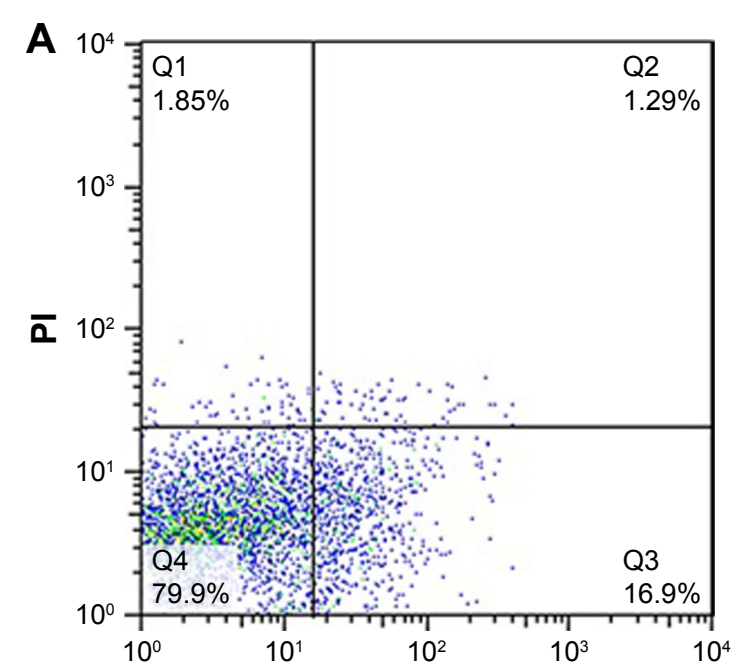

Annexin V-FITC

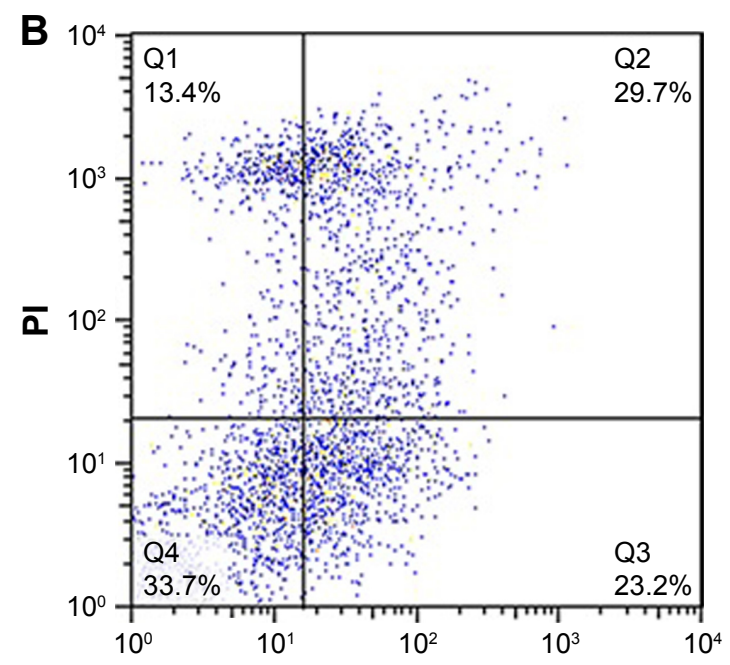

Annexin V-FITC

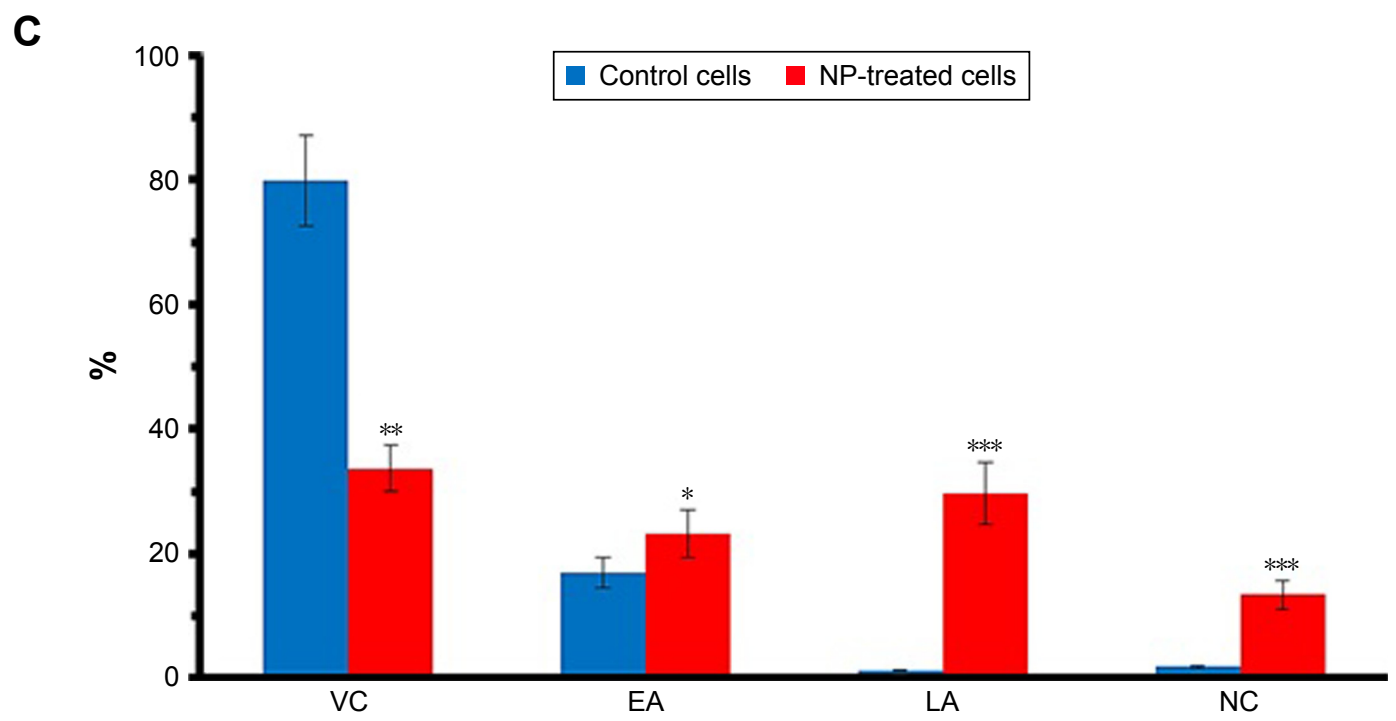

Figure 10 Lymphocyte cells were incubated with $\mathrm{IC}_{50}$ concentrations of NGOs for 24 hours and the induction of apoptosis in the absence (A) and presence of NGOs (B) was determined by flow cytometry. The quantitative analysis was plotted to show the population of VC, EA, LA, and NC cells (C).

Note: $* P<0.05, * * P<0.01$, and $* * * P<0.001$ compared with the negative control sample.

Abbreviations: VC, viable cells; EA, early apoptotic; LA, late apoptotic; NC, necrosis cells; NGO, nano graphene oxide; PI, propidium iodide; NP, nanoparticles. 

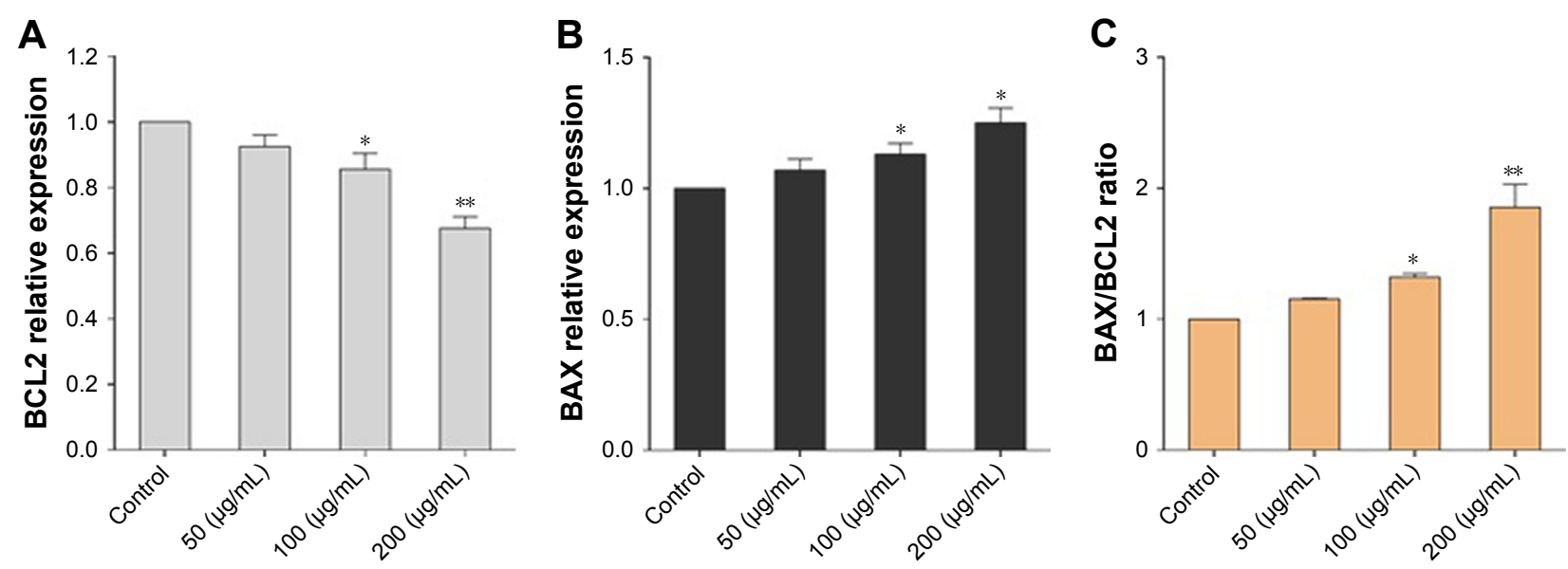

Figure II Effects of NGOs with different concentrations after 24 hours on the expression of BCL2 (A), BAX (B), relative BAX/BCL2 (C) genes in lymphocyte cells. Notes: Data were reported as mean $\pm S D$. $* P<0.05$ and $* * P<0.01$ compared to the control group. Abbreviations: NGO, nano graphene oxide; BCL2, B-cell lymphoma-2.

24 hours compared to the control group (Figure 11B). Figure $11 \mathrm{C}$, therefore shows that the relative $B A X / B C L 2$ expression increases in the NGOs-treated group compared to the control group in a dose-dependent fashion.

\section{Discussion}

NPs, natural or man-made, show a number of implementations in various fields such as physics, biology, and medicine. ${ }^{28-30}$ However, it has been reported that NPs may induce some adverse effects on the cells and proteins and stimulate several disorders associated with cellular damage and protein unfolding. ${ }^{31,32}$

NGOs are used in different areas such as biotechnology and nanomedicine. ${ }^{33,34}$ Proteins are considered to perform a number of crucial functions. The interaction of NPs with protein and their effects on Protein conformation and corresponding function are a prime domain of study these days. We studied how NPs especially NGOs interact with proteins like $\mathrm{Hb}$ and thus affect their biological functions, shedding light on the side effects of NPs. Several studies have demonstrated the importance of understanding the adverse effects of NPs, before determining their implementations in vivo. ${ }^{35}$ Indeed, studies should focus on describing the dual role of carbon-based nanomaterials in both biomedicine and toxicity issues.

Herein, we showed that NGOs induced some adverse effect on the secondary and tertiary structure of $\mathrm{Hb}$.

The interaction between $\mathrm{Hb}$ and bare cadmium sulfide quantum dots has been explored by several spectroscopic techniques under physiological $\mathrm{pH}$. It was determined that bare cadmium sulfide quantum dots substantially change the conformation of $\mathrm{Hb}$ and reduce the $\alpha$-helix content of the secondary structure. ${ }^{36}$

The binding of silver NPs to bovine Hb was also investigated by several spectroscopic techniques. ${ }^{37}$ The Soret spectrum of $\mathrm{Hb}$ in the presence of silver NPs depicted substantial intensity alteration, which revealed that the heme moieties of $\mathrm{Hb}$ were degraded by silver NPs. The fluorescence outcome displayed that NP binding to $\mathrm{Hb}$ is carried out with a single binding site through a dynamic quenching complex. NPs could quench the fluorescence intensity of $\mathrm{Hb}$. The $\mathrm{CD}$ investigation exhibited a secondary structural alteration of $\mathrm{Hb}$ in the presence of silver NPs. The helicity of $\mathrm{Hb}$ substantially decreased by increasing concentrations of silver NP. ${ }^{37}$

The interaction between bovine $\mathrm{Hb}$ and zinc oxide NPs showed the static mode of fluorescence quenching of $\mathrm{Hb}$ by zinc oxide NPs. ${ }^{38}$ The binding of zinc oxide NPs to $\mathrm{Hb}$ was a spontaneous interaction in which electrostatic forces contributed as the main forces in complex formation. The $\mathrm{CD}$ minima showed that $\alpha$-helicity of $\mathrm{Hb}$ decreased by increasing concentrations of zinc oxide NPs. ${ }^{38}$

The interaction of $\mathrm{Fe}_{2} \mathrm{O}_{3} \mathrm{NPs}$ with $\mathrm{Hb}$ was evaluated by multi-spectroscopic techniques. ${ }^{39}$ Hydrophobic forces were determined to be the predominant intermolecular interactions to stabilize the complex. The $\mathrm{CD}$ investigations showed marginal side effects of $\mathrm{Fe}_{2} \mathrm{O}_{3}$ NPs on the secondary structural changes of $\mathrm{Hb}^{39}$

The interaction between gold NPs and bovine $\mathrm{Hb}$ showed that there was a strong interaction between gold NPs and $\mathrm{Hb}^{40}$ The hydrophobic interactions and hydrogen bonds demonstrated a crucial role in the formation of the complex. 
Changes of $\mathrm{Hb}$ secondary structure in the presence of gold NPs were also demonstrated by CD spectroscopy. ${ }^{40}$

The interaction of $\mathrm{Hb}$, gamma globulin, and transferrin with hydroxyl group-modified multi-walled carbon nanotubes was explored by several spectroscopic methods. ${ }^{41}$ Probable changes around the aromatic microenvironment of these proteins were shown. Also, possible alterations toward their secondary structure after interactions with modified multi-walled carbon nanotubes were revealed. Further investigations by CD spectroscopy exhibited the loss of $\alpha$-helical structures. This investigation provided useful information regarding the biosafety profile of functionalized multi-walled carbon nanotubes for their in vivo biomedical implementations. ${ }^{41}$

The interaction of nanodiamond and silicon dioxide NPs with $\mathrm{Hb}$ also showed secondary and tertiary structural changes of $\mathrm{Hb}^{42,43}$

It has been shown that fullerene NPs synthesized by different methods induce various impacts on human serum albumin and bovine serum albumin conformations. The crucial difference between the two investigations was the fabrication methods of fullerene NPs, and principal differences between the main NPs fabricated by the two methods were the NP size distributions. ${ }^{44,45}$ Therefore, it can be speculated that NP size distribution might be the key factor leading to different binding affinities of NPs to serum proteins. ${ }^{46}$

In the cellular investigations, it was revealed that NGOs stimulated cytotoxicity in a concentration-dependent manner. The probable mechanism of cytotoxicity was suggested to be triggered by ROS production, cell cycle arrest, and apoptosis induction through the $B A X$ and $B C L 2$ pathway.
The cytotoxicity of NGO and graphene in human erythrocytes and skin fibroblasts has been also studied. ${ }^{47}$ It was proved that at the smallest size, NGOs induced the greatest hemolytic activity, whereas agglomerated graphene sheets displayed the lowest hemolytic activity. Modifying NGOs with chitosan significantly reduced the hemolytic activity. Together, these data indicate that NP dimension and surface modification of NPs show a substantial effect on the biological behaviors of red blood cells. In addition, the cytotoxicity of NGOs and graphene sheets was depicted by assaying mitochondrial activity in human skin fibroblasts. It was demonstrated that the dense graphene sheets are more cytotoxic to fibroblasts than the less compact NGOs. Distinctly, adverse effects of graphene and NGOs depend on the colloidal stability of NPs and mode of interactions. ${ }^{47}$

Comparison of cellular uptake and cytotoxicity of multiwalled carbon nanotubes, NGOs, and nanodiamond displayed that all of these NPs were easily infiltrated by HeLa cells through nonspecific cellular internalization in the following order: nanodiamond $>$ multi-walled carbon nanotubes $>$ NGOs. It was revealed that these NPs have a dose- and timedependent toxicity against HeLa cells. ${ }^{48}$

Some other studies regarding the cytotoxicity of GO have been summarized in Table 3 .

Also, in order to determine the mitochondrial apoptosis induction stimulated by NGOs in lymphocyte cells, we explored the influence of NGOs on the expression of BCL2 and $B A X$ in vitro. The expression of $B C L 2$ in lymphocyte cells treated with NGOs (100 and $200 \mu \mathrm{g} / \mathrm{mL})$ markedly decreased in comparison to the control. $B A X$ revealed a significant increase in the lymphocyte cells treated with NGOs

Table 3 Summary of already published papers regarding the interaction of NGOs with different cells

\begin{tabular}{|c|c|c|c|}
\hline NP & Cell line & Outcome & References \\
\hline NGOs & Human lung cells (BEAS-2B) & Induction of apoptosis & 49 \\
\hline NGOs and SWCNT & Human hepatoma HepG2 & $\begin{array}{l}\text { Protein profile showed oxidized SWCNTs } \\
\text { stimulated more oxidative stress than GO }\end{array}$ & 50 \\
\hline NGOs and & HUVEC, human osteosarcoma & ROS-mediated DNA breakage in & 51 \\
\hline reduced GO & $\begin{array}{l}\text { cell line (MG-63), and human } \\
\text { keratinocytes cell line }(\mathrm{HaCaT})\end{array}$ & GO-treated cells & \\
\hline NGOs & HLF cells & Severe genotoxicity & 52 \\
\hline $\begin{array}{l}\text { NGOs and carboxyl } \\
\text { graphene }\end{array}$ & $\begin{array}{l}\text { Human hepatocellular carcinoma } \\
\text { cell line HepG2 }\end{array}$ & $\begin{array}{l}\text { Both carbon NPs induced plasma } \\
\text { membrane leakage and induction of ROS }\end{array}$ & 53 \\
\hline Pegylated NGOs & $\begin{array}{l}\text { Human Saos- } 2 \text { osteoblasts, } \\
\text { human HepG } 2 \text { hepatocytes, and } \\
\text { murine RAW-264.7 macrophages }\end{array}$ & $\begin{array}{l}\text { Different mechanisms in PEG-GOs } \\
\text { internalization based on each cell type }\end{array}$ & 54 \\
\hline NGOs & Colon carcinoma (Caco-2) & Biocompatible GO & 55 \\
\hline $\begin{array}{l}\text { Lead sulfide/reduced } \\
\text { GO quantum dots }\end{array}$ & Human mononuclear blood cells & No cytotoxicity up to $200 \mu \mathrm{g} / \mathrm{mL}$ & 56 \\
\hline
\end{tabular}

Abbreviations: GO, graphene oxide; NGO, nano graphene oxide; HUVEC, human umbilical vascular endothelial cells; NP, nanoparticle; HLF, human lung fibroblast; SWCNT, single-walled carbon nanotube. 
(100 and $200 \mu \mathrm{g} / \mathrm{mL}$ ) compared to the control group. Our data are consistent with the results of Ding et al reported that the toxic mechanism of NGOs is caused by the induction of ROS-dependent apoptosis through the BCL2 pathway. ${ }^{57}$ According to $\mathrm{Li}$ et al, NGOs could trigger macrophage apoptosis by the activation of BIM and $B A X{ }^{58}$

Therefore, it may be concluded that NGOs-induced cytotoxicity and their toxic mechanisms depend on several factors such as cell type, functional groups, and the size of NPs. To employ NGOs in medical settings, these factors should be controlled to reduce NGO-induced cytotoxicity in normal cells.

\section{Conclusion}

This research investigated the effect of NGOs on $\mathrm{Hb}$ structure and lymphocyte cell by spectroscopy, docking, cellular, and molecular studies. It was shown that NGOs can denature the quaternary and secondary structure of protein in the vicinity of Tyr residues. Also, NGOs can stimulate cytotoxicity against human lymphocyte cells through generation of ROS, cell cycle arrest, and apoptosis induction. Therefore, detailed studies on the behavior of NGOs in vivo should be designed to explore the exact mechanism driving the toxicity of NPs.

\section{Acknowledgment}

The authors would like to thank Mrs Somayeh Saadi for language editing of the paper.

\section{Disclosure}

The authors report no conflicts of interest in this work.

\section{References}

1. Yi L, Chang T, Feng X-Q, Zhang Y, Wang J, Huang B. Giant energy absorption capacity of graphene-based carbon honeycombs. Carbon N Y. 2017;118:348-357.

2. Pang Z, Gu X, Wei Y, Yang R, Dresselhaus MS. Bottom-up design of three-dimensional carbon-honeycomb with superb specific strength and high thermal conductivity. Nano Lett. 2017;17(1):179-185.

3. Chen J, Li Y, Huang L, Li C, Shi G. High-yield preparation of graphene oxide from small graphite flakes via an improved Hummers method with a simple purification process. Carbon N Y. 2015;81:826-834.

4. Ossonon BD, Bélanger D. Functionalization of graphene sheets by the diazonium chemistry during electrochemical exfoliation of graphite. Carbon N Y. 2017;111:83-93.

5. Georgakilas V, Tiwari JN, Kemp KC, et al. Noncovalent functionalization of graphene and graphene oxide for energy materials, biosensing, catalytic, and biomedical applications. Chem Rev. 2016;116(9): 5464-5519.

6. Gupta J, Prakash A, Jaiswal MK, Agarrwal A, Bahadur D. Superparamagnetic iron oxide-reduced graphene oxide nanohybrid-a vehicle for targeted drug delivery and hyperthermia treatment of cancer. J Magn Magn Mater. 2018;448:332-338.
7. Dowaidar M, Abdelhamid HN, Hällbrink M, Zou X, Langel Ü. Graphene oxide nanosheets in complex with cell penetrating peptides for oligonucleotides delivery. Biochim Biophys Acta. 2017;1861(9):2334-2341.

8. Grande CD, Mangadlao J, Fan J, et al. Chitosan Cross-Linked Graphene Oxide Nanocomposite Films with Antimicrobial Activity for Application in Food Industry. Macromol Symp. 2017;374(1).

9. Yu P, Bao RY, Shi XJ, Yang W, Yang MB. Self-assembled high-strength hydroxyapatite/graphene oxide/chitosan composite hydrogel for bone tissue engineering. Carbohydr Polym. 2017;155:507-515.

10. De S, Patra K, Ghosh D, et al. Tailoring the Efficacy of Multifunctional Biopolymeric Graphene Oxide Quantum Dot-Based Nanomaterial as Nanocargo in Cancer Therapeutic Application. ACS Biomater Sci Eng. 2018;4(2):514-531.

11. Zhang L, Peng J, Hong MF, Chen JQ, Liang RP, Qiu JD. A facile graphene oxide-based fluorescent nanosensor for the in situ "turn-on" detection of telomerase activity. Analyst. 2018;143(10):2334-2341.

12. Sun $\mathrm{B}, \mathrm{Wu} \mathrm{J}$, Cui S, et al. In situ synthesis of graphene oxide/gold nanorods theranostic hybrids for efficient tumor computed tomography imaging and photothermal therapy. Nano Res. 2017;10(1):37-48.

13. Goreham RV, Schroeder KL, Holmes A, Bradley SJ, Nann T. Demonstration of the lack of cytotoxicity of unmodified and folic acid modified graphene oxide quantum dots, and their application to fluorescence lifetime imaging of HaCaT cells. Mikrochim Acta. 2018;185(2):128.

14. Peña-Bahamonde J, San Miguel V, Nguyen HN, Ozisik R, Rodrigues DF, Cabanelas JC. Functionalization of reduced graphene oxide with polysulfone brushes enhance antibacterial properties and reduce human cytotoxicity. Carbon N Y. 2017;111:258-268.

15. Liao KH, Lin YS, Macosko CW, Haynes CL. Cytotoxicity of graphene oxide and graphene in human erythrocytes and skin fibroblasts. ACS Appl Mater Interfaces. 2011;3(7):2607-2615.

16. Li Y, Liu Y, Fu Y, et al. The triggering of apoptosis in macrophages by pristine graphene through the MAPK and TGF-beta signaling pathways. Biomaterials. 2012;33(2):402-411.

17. Alava T, Mann JA. Théodore C, Benitez JJ, Dichtel WR, Parpia JM, Craighead HG. Control of the graphene-protein interface is required to preserve adsorbed protein function. Anal Chem. 2013;85(5): 2754-2759.

18. De M, Chou SS, Dravid VP. Graphene oxide as an enzyme inhibitor: modulation of activity of $\alpha$-chymotrypsin. J Am Chem Soc. 2011;133(44) $17524-17527$

19. Alam P, Rabbani G, Badr G, Badr BM, Khan RH. The surfactantinduced conformational and activity alterations in Rhizopus niveus lipase. Cell Biochem Biophys. 2015;71(2):1199-1206.

20. Hanwell MD, Curtis DE, Lonie DC, Vandermeersch T, Zurek E, Hutchison GR. Avogadro: an advanced semantic chemical editor, visualization, and analysis platform. J Cheminform. 2012;4(1):17.

21. Ritchie DW, Venkatraman V. Ultra-fast FFT protein docking on graphics processors. Bioinformatics. 2010;26(19):2398-2405.

22. Moosavi MA, Sharifi M, Ghafary SM, et al. Photodynamic $\mathrm{N}-\mathrm{TiO}_{2}$ Nanoparticle Treatment Induces Controlled ROS-mediated Autophagy and Terminal Differentiation of Leukemia Cells. Sci Rep. 2016;6:34413

23. Wang G, Yang J, Park J, et al. Facile synthesis and characterization of graphene nanosheets. J Phys Chem C. 2008;112(22):8192-8195.

24. Çiplak Z, Yildiz N, Çalimli A. Investigation of Graphene/Ag nanocomposites synthesis parameters for two different synthesis methods. Fullerenes Nanotubes Carbon Nanostruct. 2015;23(4):361-370.

25. Zeinabad HA, Kachooei E, Saboury AA, et al. Thermodynamic and conformational changes of protein toward interaction with nanoparticles: a spectroscopic overview. $R S C A d v$. 2016;6(107):105903-105919.

26. Sabziparvar N, Saeedi Y, Nouri M, et al. Investigating the Interaction of Silicon Dioxide Nanoparticles with Human Hemoglobin and Lymphocyte Cells by Biophysical, Computational, and Cellular Studies. J Phys Chem B. 2018;122(15):4278-4288.

27. Aghili Z, Taheri S, Zeinabad HA, et al. Investigating the interaction of Fe nanoparticles with lysozyme by biophysical and molecular docking studies. PLoS One. 2016;11(10):e0164878. 
28. Yao J, Yang M, Duan Y. Chemistry, biology, and medicine of fluorescent nanomaterials and related systems: new insights into biosensing, bioimaging, genomics, diagnostics, and therapy. Chem Rev. 2014;114(12):6130-6178.

29. Wen AM, Infusino M, de Luca A, et al. Interface of physics and biology: engineering virus-based nanoparticles for biophotonics. Bioconjug Chem. 2015;26(1):51-62.

30. Shin TH, Cheon J. Synergism of Nanomaterials with Physical Stimuli for Biology and Medicine. Acc Chem Res. 2017;50(3):567-572.

31. Stone V, Miller MR, Clift MJD, et al. Nanomaterials versus ambient ultrafine particles: an opportunity to exchange toxicology knowledge. Environ Health Perspect. 2017;125(10):106002.

32. Vranic S, Gosens I, Jacobsen NR, et al. Impact of serum as a dispersion agent for in vitro and in vivo toxicological assessments of $\mathrm{TiO}_{2}$ nanoparticles. Arch Toxicol. 2017;91(1):353-363.

33. Jing G, Wang Z, Zhuang X, et al. Suspended graphene oxide nanosheets maintain the self-renewal of mouse embryonic stem cells via downregulating the expression of Vinculin. Biomaterials. 2018;171:1-11.

34. Deng W, Qiu J, Wang S, et al. Development of biocompatible and VEGF-targeted paclitaxel nanodrugs on albumin and graphene oxide dual-carrier for photothermal-triggered drug delivery in vitro and in vivo. Int J Nanomedicine. 2018;13:439-453.

35. Gajalakshmi S, Mukherjee A, Chandrasekaran N. Interaction of carbon nanomaterials with biological matrices. Environmental Toxicity of Nanomaterials. Boca Raton, Florida, USA: CRC Press; 2018: 91-122.

36. Shen XC, Liou XY, Ye LP, Liang H, Wang ZY. Spectroscopic studies on the interaction between human hemoglobin and $\mathrm{CdS}$ quantum dots. J Colloid Interface Sci. 2007;311(2):400-406.

37. Zolghadri S, Saboury AA, Golestani A, Divsalar A, Rezaei-Zarchi S, Moosavi-Movahedi AA. Interaction between silver nanoparticle and bovine hemoglobin at different temperatures. J Nanoparticle Res. 2009; 11(7):1751-1758.

38. Mandal G, Bhattacharya S, Ganguly T. Investigations to reveal the nature of interactions between bovine hemoglobin and semiconductor zinc oxide nanoparticles by using various optical techniques. Chem Phys Lett. 2009;478(4-6):271-276.

39. Zolghadri S, Saboury AA, Amin E, Moosavi-Movahedi AA. A spectroscopic study on the interaction between ferric oxide nanoparticles and human hemoglobin. J Iranian Chem Soc. 2010;7(S2):S145-S153.

40. Yang W, Sun L, Weng J, Chen L, Zhang Q. Probing the interaction of bovine haemoglobin with gold nanoparticles. IET Nanobiotechnol. 2012;6(1):26-32.

41. Sekar G, Kandiyil ST, Sivakumar A, Mukherjee A, Chandrasekaran N. Binding studies of hydroxylated Multi-Walled Carbon Nanotubes to hemoglobin, gamma globulin and transferrin. J Photochem Photobiol B. 2015;153:222-232.

42. Pishkar L, Taheri S, Makarem S, et al. Studies on the interaction between nanodiamond and human hemoglobin by surface tension measurement and spectroscopy methods. J Biomol Struct Dyn. 2017;35(3): $603-615$.
43. Sabziparvar N, Saeedi Y, Nouri M, et al. Investigating the Interaction of Silicon Dioxide Nanoparticles with Human Hemoglobin and Lymphocyte Cells by Biophysical, Computational, and Cellular Studies. J Phys Chem B. 2018;122(15):4278-4288.

44. Song M, Liu S, Yin J, Wang H. Interaction of human serum album and $\mathrm{C}_{60}$ aggregates in solution. Int J Mol Sci. 2011;12(8):4964-4974.

45. Liu S, Sui Y, Guo K, Yin Z, Gao X. Spectroscopic study on the interaction of pristine $\mathrm{C} 60$ and serum albumins in solution. Nanoscale Res Lett. 2012;7(1):433.

46. Fu X, Fang Y, Zhao H, Liu S. Size-dependent binding of pristine fullerene (nC 60) nanoparticles to bovine/human serum albumin. J Mol Struct. 2018;1166:442-447.

47. Liao KH, Lin YS, Macosko CW, Haynes CL. Cytotoxicity of graphene oxide and graphene in human erythrocytes and skin fibroblasts. ACS Appl Mater Interfaces. 2011;3(7):2607-2615.

48. Zhang X, Hu W, Li J, Tao L, Wei Y. A comparative study of cellular uptake and cytotoxicity of multi-walled carbon nanotubes, graphene oxide, and nanodiamond. Toxicol Res. 2012;1(1):62-68.

49. Vallabani NV, Mittal S, Shukla RK, et al. Toxicity of graphene in normal human lung cells (BEAS-2B). J Biomed Nanotechnol. 2011; 7(1):106-107.

50. Yuan J, Gao H, Sui J, Duan H, Chen WN, Ching CB. Cytotoxicity evaluation of oxidized single-walled carbon nanotubes and graphene oxide on human hepatoma HepG2 cells: an iTRAQ-coupled 2D LC-MS/ MS proteome analysis. Toxicol Sci. 2012;126(1):149-161.

51. Das S, Singh S, Singh V, et al. Oxygenated functional group density on graphene oxide: its effect on cell toxicity. Part Part Syst Char. 2013; 30(2):148-157.

52. Wang A, Pu K, Dong B, et al. Role of surface charge and oxidative stress in cytotoxicity and genotoxicity of graphene oxide towards human lung fibroblast cells. J Appl Toxicol. 2013;33(10):1156-1164.

53. Lammel T, Boisseaux P, Fernández-Cruz ML, Navas JM. Internalization and cytotoxicity of graphene oxide and carboxyl graphene nanoplatelets in the human hepatocellular carcinoma cell line Hep G2. Part Fibre Toxicol. 2013;10(1):27.

54. Linares J, Matesanz MC, Vila M, et al. Endocytic mechanisms of graphene oxide nanosheets in osteoblasts, hepatocytes and macrophages. ACS Appl Mater Interfaces. 2014;6(16):13697-13706.

55. Nguyen TH, Lin M, Mustapha A. Toxicity of graphene oxide on intestinal bacteria and Caco-2 cells. J Food Prot. 2015;78(5):996-1002.

56. Ayoubi M, Naserzadeh P, Hashemi MT, et al. Biochemical mechanisms of dose-dependent cytotoxicity and ROS-mediated apoptosis induced by lead sulfide/graphene oxide quantum dots for potential bioimaging applications. Sci Rep. 2017;7(1):12896.

57. Ding Z, Zhang Z, Ma H, Chen Y. In vitro hemocompatibility and toxic mechanism of graphene oxide on human peripheral blood T lymphocytes and serum albumin. ACS Appl Mater Interfaces. 2014;6(22): 19797-19807.

58. Li Y, Liu Y, Fu Y, et al. The triggering of apoptosis in macrophages by pristine graphene through the MAPK and TGF-beta signaling pathways. Biomaterials. 2012;33(2):402-411.
International Journal of Nanomedicine

\section{Publish your work in this journal}

The International Journal of Nanomedicine is an international, peerreviewed journal focusing on the application of nanotechnology in diagnostics, therapeutics, and drug delivery systems throughout the biomedical field. This journal is indexed on PubMed Central, MedLine, CAS, SciSearch ${ }^{\circledR}$, Current Contents ${ }^{\circledR} /$ Clinical Medicine,
Dovepress

Journal Citation Reports/Science Edition, EMBase, Scopus and the Elsevier Bibliographic databases. The manuscript management system is completely online and includes a very quick and fair peer-review system, which is all easy to use. Visit http://www.dovepress.com/ testimonials.php to read real quotes from published authors. 